\title{
IS DISRUPTIVE EMPLOYEE BEHAVIOR IN EXPORT PROCESSING ZONES (EPZS) INFLUENCED BY THEIR EMPLOYMENT IN FIRMS SITUATED IN PUBLIC OR PRIVATE ZONES?
}

\author{
KARIUKI M SIMON \\ NICO J SMITH \\ Faculty of Commerce and Administration, \\ Department of Business Management \\ University of Zululand \\ simior@yahoo.com \\ nicosmit@twr.ac.za
}

\begin{abstract}
The Kenyan government's Export processing zone (EPZ) policy has conceded large parts of existing labour laws to EPZ investors. This article sets out to establish whether there is a difference in the working conditions employers in the public and private zones expose their workers to and from which zone possible disruptive employee behaviours emanate from. A random sample of 376 employees was selected from EPZ garment firms located in both private and public zones. Statistical procedures were applied to determine possible differences. The findings indicate that employees from companies in the private zones were exposed to better working conditions than those employed in companies located in the public zone, which explains why disruptive employee behaviour originates from the public zone. It is recommended that working conditions of companies in the pubic zone should be improved.
\end{abstract}

\section{OPSOMMING}

Die regering se uitvoerprosesseringsbeleid (EPZ) het toegewings in terme van bestaande arbeidswetgewing aan EPZ investeerders gedoen. Hierdie artikel het ten doel om vas te stel of daar 'n verskil bestaan in die werktoestande waaraan werkgewers in die openbare en private sones hulle werknemers blootstel en van watter sone moontlike ontwrigtende gedrag hul oorsprong het. 'n Ewekansige steekproef van 376 werknemers is uit EPZ kledingfirmas in beide die private en openbare sones getrek. Statistiese prosedures is gebruik om moontlike verskille te bepaal. Die bevindinge dui daarop dat werknemers van maatskappy uit private sones aan beter werkstoestande blootgestel is teenoor dié wat uit die publieke sone afkomstige is, wat ook verklaar waarom ontwrigtende gedrag uit die openbare sone onstaan. Dit word aanbeveel dat werktoestande van maatskappye in die openbare sone verbeter word.

Reasons for the establishment of EPZs in developing countries

The Heckscher-Ohlin (H-O) 1924 theory is an important general framework for thinking about EPZs and a good point of departure for this paper as it raises some important issues concerning investment in EPZ host countries. The EPZ model is derived from the Heckscher-Ohlin theory on the patterns and determinants of international trade. The theory states that: a country will be able to produce at lower cost (and therefore have comparative advantage in) those products whose production requires relatively large amounts of the factors of production (also known as factor endowments e.g. land, labor, capital, natural resources) with which that country is relatively endowed (Husted \& Melvin, 2001). Labor abundant developing countries should therefore specialize in labor-intensive products adds Sloman (2000).

There are a variety of reasons as to why developing countries establish EPZs. Studies by Abeywardene (1994), Khan (2000), Madani (1998), the International Labor Organizations (ILO) (1998), Kusago et al (1998) indicate that many developing countries establish EPZs to help increase their foreign exchange, provide jobs for the educated unemployed, upgrading the skills of local manpower, create linkages with the hinterland by stimulating, technology transfer and develop underdeveloped regions in the country.

A study by Jauch et al (1996) on "EPZs in Southern Africa: Economic, Social and political implications" revealed that a large number of Southern African countries adopting EPZs had high rates of unemployment, these countries were also characterized by import-substitution strategies, low levels of

Requests for copies should be addressed to: S. Kariuki, Faculty of Commerce and Administration, Department of Business Management, University of Zululand Private Bag, KwaDlangezwa, 3886 foreign investment mainly focused on mining, declining incomes from unprocessed primary commodity exports, dwindling foreign exchange reserves and low levels of technological know-how and general economic stagnation. The study concluded by saying that the introduction of EPZs is regarded as a signal of a country's departure from import substitution strategies toward an export-oriented economy. EPZs have been appropriately described as "one aspect of the integration of national economies into the global economy."

The Kenyan EPZ program commenced in 1990, with the enactment of the EPZ act (CAP 517, Laws of Kenya) and by March 2002, 23 zones had been designated, with 15 in operation. The Kenyan government had established its own zone and had licensed 14 private ones (Export Processing Zones Authority (EPZA), 2002). According to a study by Glenday and Ndii (2000) on "Export platforms in Kenya" the main objectives of the EPZ program were to increase manufactured exports, create employment and increase export-oriented investment.

The major factors attracting investors to EPZs

According to studies by the International Confederation of Free Trade Unions (ICFTU) (1996) and the World Export Processing Zones Authority (WEPZA) (1996) investors prefer EPZs, instead of having to explore unknown territory, adapting to inadequate infrastructure and often very complex legislation, thus EPZs provide a modern predictable environment with ready-to-use infrastructure. Other incentives EPZs offer investors include the low level of capital goods required in the establishment of industries in the zones which makes it easier for such enterprises to break off their activities and repatriate their capital any time, duty free importation of raw materials, generous company income tax holidays, streamlined administration such as streamlined customs documentation the provisions of superior physical infrastructure and subsidized utilities and the ample 
supply of cheap labor Soto (1999). Studies by Abbot (1997), Hillary (1999), Hunter (2001) and the NLC (1998) indicate that EPZ investors also take advantage of relaxed labor laws and relatively lower working condition standards than those of their home countries. The investment incentives offered by the Kenyan EPZ program (2002) identify with those listed above.

As at February 2002, only one of the 23, EPZs was run (and developed) by the public sector while the other 22 were being run (and developed) by the private sector. By February 2002, 15 of the 23 zones were in operation. Eight of the other designated zones were either available for development or under construction, among the eight, one had completed constructing the buildings but had not yet been occupied. By February 2002, there were about 50 operational enterprises in the 17 zones (one public and 16 private) (EPZA, 2002)

\section{Focus of the paper}

According to the EPZA a two week strike late in January and early February 2003, that emanated from the public zone and spread over to the private zones made the EPZs loose Ksh. 800 million (approx. US\$ 10 million or R100 million). Six foreign investors also shelved plans to open industries in the country (Bosire, 2003). To avoid or to be able to predict trends in the origin and spread of disruptive employee behavior across the zones (from public to private zones and vice versa) an investigation into the working condition practices that employers located in the public and private zones expose their workers to is therefore necessary to determine the salient issues that negatively influence the perceptions and attitudes of EPZ employees towards their working conditions.

More specifically this paper attempts to explore whether the attitudes and perceptions of Kenyan garment EPZ employees from companies located in the public and the private zones towards the state of their working conditions are influenced by similar factors; and whether the state of the working conditions in private and public EPZ garment firms' are similar. The assumption being that there are no significant differences in the attitudes and perceptions of EPZ workers from companies located in the public zone as well as those employed by companies located in the private zones.

\section{METHOD}

This study was conducted as an ex post facto research. As it examined how specific independent variables (in this study's case: education qualifications, length of service, and the employment status) affected the dependent variable(s) (working conditions). The population of the study consisted of all Kenyan garment EPZ employees. The target population consisted of 16 garment firms, which employed 14,817 employees. Random and purposeful sampling was used to select the subjects of this study. According to the Krejcie and Morgan table on the configuration of sample sizes cited in Leedy (1997), a sample of 375 cases should be selected from a population of 15,000 cases. The researcher thus selected 376 employees and responses were received from 302 respondents, which represented an 80 per cent response rate. Uhl and Schoner (1969) state that a response rate of at least $75 \%$ should be achieved though beyond this there is little gain in accuracy. Welman \& Kruger, (2001) also indicate that a response rate of less than $50 \%$ of a selected sample presents an entirely incorrect picture of the population.

Questionnaires were the main data collection instruments used.

The rules and regulations contained in the codes of conduct of about 30 Multi-National Enterprises (MNEs) heavily involved in EPZ operations, consumer and human rights Non Governmental Organizations (NGOs) such as the United Nations (UN), the (ILO) among many others were converted into questions which were then posed to the EPZ employees from companies located in the public zone and those employed by companies located in the private zones to identify (i) what factors significantly influenced their perceptions towards their working conditions and (ii) whether the state of working conditions in EPZ garment firms' was similar.

The contents of these codes of conduct were then grouped into seven broad categories, which include:

- Education and training facilities (four items/questions)

- Remuneration structures (five items/questions)

- Employment structures (avoid employment discrimination) (three items/questions)

- Working facilities (five items/questions)

- Interpersonal relationships (two items/questions)

- Working relationships (four items/questions)

- Dispute resolution structures (seven items/questions)

These items (questions) that made up each of these seven categories were then converted into a questionnaire. The responses to these questions were then rated on a four point Likert rating scale where scoring was done as follows:
Positively stated items

Always, Strongly agree, Very

Agree, Often, Good

Disagree, Sometimes, Fair

Never, Strongly disagree, Poor
Negatively stated items

4 Always, Strongly agree, Very

3 Agree, Often, Good

2 Disagree, Sometimes, Fair

1 Never, Strongly disagree, Poor
The mean scores were then calculated for the responses obtained for the range of items in the seven categories listed above to show the perceptions of both sets of employees towards the state of their working conditions. The mean scores obtained thus gave an overall perception of both sets of employees' attitudes towards each EPZ working condition item (question) contained in each of the seven broad categories. These means were then compared to determine which set of employees had a higher score than the other. When one group had a higher mean score on an item than the other it was interpreted to mean that, that group (the one with a high mean) perceived that item better than the other group.

In analyzing what factors significantly influenced EPZ employees from companies located in the public and private zones attitudes and perceptions towards their working conditions the Analysis Of Variance (ANOVA) (f-test) was used to test for significant differences. To test null hypothesis $\mathrm{Ho}_{1} \mathrm{Ho}_{2}$ and $\mathrm{Ho}_{3}$ the ANOVA test, was used. The 0.05 level of confidence was used to reject or not reject each of the hypotheses.

NB: Each of the hypotheses was tested twice one test being done for employees from companies located in the public zone and another one being done for employees located in private zones. (Tables are only provided for results that had significant relationships).

\section{RESULTS}

The impact of the various labor law exemptions on Investors located in private and public EPZs

Investors located in the public zone rated the exemptions from the factories act and from paying the minimum wage higher than investors from companies located in the private zones. On the basis of this finding it can therefore be concluded that the exemption from applying the factories act and from paying minimum wages had contributed significantly to the operations of investors located in public but not those from companies located in private zones. 
Factors that significantly affect labor relations between employees working for EPZ companies located in private and the public zones

After exposing nine factors that were assumed to influence the attitudes and perceptions of EPZ workers from companies located in both the public and private zones towards the state of their working conditions to appropriate statistical tests (t-tests or f-tests) three factors; education qualifications, length of service, and the employment status of an employee in the zones were found to significantly influence the attitudes of EPZ workers from companies located in both public and private zones towards their working conditions.

Table 1 present the results related to the first hypothesis, which stated that the education qualifications of EPZ employees from companies located in public and private zones does not affect their attitudes towards the state of their working conditions.

\section{TABLE 1}

ANALYsis of THE VARIANCE FOR EDUCATION QUaLifications AND EMPLOYEES FROM COMPANIES LOCATED IN PRIVATE ZONES Perceptions ToWARdS THE STATE OF THEIR Working Conditions

\begin{tabular}{lcccc}
\hline $\begin{array}{l}\text { Employees from } \\
\text { Private Zones }\end{array}$ & Sum of Squares & DF & Mean Square & F \\
\hline Between Groups & 196.656 & 3 & 65.552 & 3.104 \\
Within Groups & 2766.944 & 131 & 21.122 & \\
Total & 2963.600 & 134 & & \\
\hline
\end{tabular}

(Critical value 2.67)

Table one above indicates that the f ratio (3.104) was greater than the critical value (2.67) which indicates that there was a significant relationship between the educational qualifications of EPZ employees from companies located in the private zones and their attitudes towards the state of their working conditions. On the basis of this finding the null hypothesis was rejected.

A similar f-test was also carried out to determine whether the education qualifications of EPZ employees from companies located in public zones affected their attitudes towards the state of their working conditions revealed no significant relationship. On the basis of these results the null hypothesis (for the public zone employees) was not rejected.

Table 2 presents the results related to the second hypothesis, which stated that the length of service of EPZ employees from companies located in public and private zones does not affect their attitudes towards the state of their working conditions.

TABLE 2

ANALYSIS OF THE VARIANCE FOR LENGTH OF SERVICE AND EMPLOYEES FROM COMPANIES LOCATED IN PUBLIC AND PRIVATE ZONES Perceptions Towards THE STATE OF THEIR WORKING CONDITIONS

\begin{tabular}{lcccc}
\hline $\begin{array}{l}\text { Employees from } \\
\text { Private Zones }\end{array}$ & Sum of Squares & DF & Mean Square & F \\
\hline Between Groups & 226.657 & 4 & 56.664 & 2.691 \\
Within Groups & 2736.943 & 130 & 21.053 & \\
Total & 2963.600 & 134 & & \\
\hline
\end{tabular}

Table 2 above indicates that the f ratio (2.691) was greater than the critical value (2.43), which indicates that there was a significant relationship between the length of service of EPZ employees from companies, located in the private zones and their attitudes towards the state of their working conditions. On the basis of this finding the null hypothesis was rejected. A similar f-test was also carried out to determine whether the length of service of EPZ employees from companies located in the public zone affected their attitudes towards the state of their working conditions revealed no significant relationship. On the basis of these results the null hypothesis (for the public zone employees) was not rejected.

Table 3 present the results related to the third hypothesis, which stated that the employment status of EPZ employees from companies located in public and private zones does not affect their attitudes towards the state of their working conditions

TABLE 3

ANalysis OF THE VARIANCE For EMPloyment STATUS AND EMPLOYEES FROM COMPANIES LOCATED IN PRIVATE Zones Perceptions ToWARds THE STATE OF THEIR Working Conditions

\begin{tabular}{lcccc}
\hline $\begin{array}{l}\text { Employees from } \\
\text { Private Zones }\end{array}$ & Sum of Squares & DF & Mean Square & F \\
\hline Between Groups & 249.121 & 2 & 124.560 & 6.057 \\
Within Groups & 2714.479 & 132 & 20.564 & \\
Total & 2963.600 & 134 & & \\
\hline
\end{tabular}

Table 3 above indicates that the $\mathrm{f}$ ratio (6.057) was greater than the critical value (3.91), which indicates that there was a significant relationship between the employment status of EPZ employees from companies, located in the private zones and their attitudes towards the state of their working conditions. On the basis of this finding the null hypothesis was rejected. A similar f-test carried out to determine whether the length of service of EPZ employees from companies located in the public zone affected their attitudes towards the state of their working conditions revealed no significant relationship. On the basis of these results the null (for the public zone employees) hypothesis was not rejected.

The scope of the labor relations' gap in Kenyan EPZs The five subsections that follow below point out areas where a labor relation's gap exists between the perceptions of employees from companies located in the public and the private zones.

Education, Training and Work Experience

EPZ employees from companies located in the private zones had higher mean perception scores than employees from companies located in the public zone in all the five items that were tested under the education and training structures category. On the basis of this finding it can therefore be concluded that EPZ employees from companies located in the private zones were exposed to better education and training structures than their co-workers employed in companies located in the public zone.

\section{Employment Discrimination}

EPZ employees from companies located in the private zones had higher mean perception scores than their co-workers employed by companies located in the private zone in all the four items tested in the employment discrimination category. This means that employment discrimination on the basis of age or gender was higher in companies located in the public zone than in those located in the private zones. This finding partially supports those of Abbott (1997), Hillary (1999) and 
Hunter R. (2000) whose studies indicate that EPZ employees experience various forms of discrimination at the EPZ workplace.

\section{Remuneration structures}

EPZ employees from companies located in the private zones had higher mean perception scores than their coworkers employed by firms located in the public zone in four out of the five items that were tested in the remuneration structures category. This can be interpreted to mean that, on average employees from companies located in the private zones had better remuneration structures than their coworkers from companies located in the public zone. This finding partially confirms the findings of the ICFTU (1996), Hunter, (2001) and the NLC (undated) which all indicated that EPZ wages quite low.

\section{Working facilities}

EPZ employees from companies located in the private zones had higher mean perception scores than employees from companies located in the public zones in four out of the five items tested in the working facilities category. This means that on average, EPZ employees from companies located in the private zones were exposed to better working conditions than their colleagues from companies located in the public zones. This finding partially supports those of Abbot (1997) and Hillary (1999) whose studies indicated that EPZ employees were exposed to poor working conditions.

\section{Interpersonal relationships}

EPZ employees from companies located in the private zones had higher mean perception scores than their co-workers from companies located in the public zone in the two items tested under the interpersonal relationships category. This means that EPZ employees from companies located in the private zones had better employer-employee interpersonal relationships than their co-workers from companies located in the public zones.

\section{Working relationships}

EPZ workers from companies located in the private zones had higher mean perception scores than their co-workers from companies located in the public zone in the four items examined under the state of EPZ working relationships category. This can be interpreted to mean that EPZ employees from companies located in the private zones have better employer-employee working relationships than employees from companies located in the public zone.

\section{The perceptions of EPZ investors and other Kenyan EPZ stakeholders towards the effectiveness of the existing problem-solving (regulation) frameworks}

\section{Unions/workers bodies}

EPZ employees from companies located in the private zone had higher mean perception scores than their co-workers from companies located in the public zone in the two items examined under the effectiveness of unions/workers bodies as employer-employee dispute settlement structures. This indicates that EPZ workers from companies located in the private zones had more effective unions/workers bodies than their co-workers from companies located in the public zone. This finding partly supports those of Hillary (1999) who found that unions had not been of help to EPZ workers at the EPZ workplace.

\section{The EPZA}

EPZ employees from companies located in the private zone had higher mean perception scores than their co-workers from companies located in the public zone in all the three items examined under the effectiveness of the EPZA as an employeremployee dispute settlement structure. This means that the
EPZA as a dispute settlement body has been more effective in companies located in the private zones than in companies located in the public zone.

\section{Codes of conduct}

EPZ workers from companies located in the private zones had a higher mean perception score than their co-workers from companies located in the public zone on the item tested under the effectiveness of MNE codes of conduct as dispute settlement structures at the EPZ workplace. This indicates that employees from companies located in the private zones are more aware of the MNE codes of conduct that their companies contract from than their co-workers from companies located in the public zone.

\section{DISCUSSION}

Education qualifications, length of service and the employment status of EPZ employees from companies located in the private zones are the factors that shape their perceptions towards the state of their working conditions. On the other hand no major factors were identified that influenced the perceptions and attitudes of EPZ employees from companies located in the public zones towards the state of their working conditions.

The state of EPZ remuneration structures, education/training structures, employment structures, working facilities, interpersonal relationships and the effectiveness of unions in the EPZ workplace were found to be more favorable by EPZ workers from companies located in the private zones while EPZ workers located in the public zone found the state of these items to be less favorable to them.

It is the opinion of this researcher based on the responses of both sets of EPZ employees' that the EPZ garment firms located in the private zones expose their workers to superior working conditions than those located in the public zone. It is therefore necessary for EPZ employers from companies located in the public zone to narrow down this working conditions imbalance that seems to be negatively affecting their employees who in turn spread their disruptive behavior to employees located in the private zones, which ends up disrupting EPZ operations in Kenya.

\section{REFERENCES}

Abbott, J. (1997). Export Processing Zones and the developing world. Contemporary Review, 00107565, Vol. 270, Issue 1576, p232, 6p.

Abeywardene, J., et al. (1994). Export processing zones in Sri Lanka: Economic impact and social issues. MEP, WP No. 69, Geneva: ILO. 94:5, 12-19, 23, 30-40)

Bosire, J. (2003, February). Sh800m lost in strikes at EPZ: Six firms shelve plans to invest in Kenya. Nairobi: Nation Media Group [Online]. Available: http://www.nationaudio.com/News/ DailyNation/Today/Business/Business1.html Date of access: (26-02-2003).

EPZA. (2002). Information for prospective EPZ investors. Nairobi: EPZA.

Glendy, G. \& Ndii D. (2000, February). Export Platforms in Kenya. Harvard: Harvard Institute for International Development, Harvard University (Discussion paper no.752; 00: 10, 11, 12, 13, 23).

Hilary, A. (1999, November). Endangering women's health for profit: Health and safety in Mexico's Maquiladoras. Development in Practice, 09614524, Nov99, Vol. 9, Issue 5 http://www.transnationale.org/pays/epz.htm, Date of access: (09-06-2002).

Hunter, R. et al. (2001, February 11). First Impressions of the San Marcos Free Trade Zone. National Labor Committee, [Available on internet]: http://www.nlcnet.org/behindclosed/elsalvador.htm, Date of access: (05-09-2001). 
Husted, S. \& Melvin, M. (2001). International economics, $5^{\text {th }}$ ed. Boston: Addison Wesley Longman Inc.

ICFTU. (1996). Behind the wire: Anti union repression in EPZs. Online available at: http://www.transnationale.org/anglais/ sources/tiersmonde/zones_franches_icftu_epz.htm, Date of access: (02-06-2002).

ILO. (1998, September). Export processing zones growing steadily, providing a major source of job creation. Labor/productivity problems continue to mount. Geneva: ILO. Online available at: http://www.ilo.org/public/english/bureau/inf/magazine/ 27/news.htm Date of access: (08-05-2001).

Jauch, H. et al. (1996). Export Processing Zones in Southern Africa: Economic, Social and Political Implications. Cape Town: International Labor Resource and Information Group (ILRIG). Online available at: http://aidc.org.za/ilrig/research/ epz_namibia.html Date of access: (05-09-2001).

Khan, F. (2000). Labor: Making Export processing zones more worker friendly. Cape Town: Inter Press Service (END/IPS/fk/sm/00). Online available at: http://www.oneworld.org/ips2/apr00/ 12_00_040.html Date of access: (05-06-2002).

Kusago, T. et al. (1998). Export processing zones; A review in need of update. Washington D.C.: World Bank social protection discussion paper; no. SP 9802. Report no. 20046. Online available at: http://www-wds.org/servlet/WDS_Ibank_ Servlet?pcont $=$ details\&eid=00094946_000305302247 Date of access: (12-05-2001).
Leedy, P. D. (1997). Practical research: planning and design, $6^{\text {th }}$ ed. Upper Saddle River, NJ: Merrill.

Madani, D. (1999, November). A review of the role and impact of export processing zones. Washington D.C.: Trade and development research group. World Bank research working paper no. 2238. Online available at: http://wbln0018. worldbank.org/research/workpapers.nsf/\%28allworkingpap ers\%29/042A38E8445ED9BE8525682C006733AE?OpenDocu mentD9BE Date of access: (12-05-2001).

National Labor Committee (NLC). (1998). Young Women in free trade zones injected with depro provera: National labor committee calls for investigation. Online available at: http://www.nlcnet.org/hondurus/depropro.htm Date of access: (05-06-2002)

Sloman, J. (2000). Economics, $4^{\text {th }}$ ed. Harrow: Prentice Hall.

Soto, G. (1999). The case against free Export Processing Zones. Online available at: http://www.stanford.edu/class/e297c/ trade_environment/rights/hfree.html Date of access: (05-092001).

Uhl, K.P. \& Schoner, B. (1969). Marketing research: Information systems and decision-making. New York: John Wiley \& Sons Inc.

Welman, J.C. \& Kruger, S. J. (2001). Research methodology. Cape Town: Oxford University Press Southern Africa.

WEPZA. (1996). Behind the wire: WEPZA comments and questions. Online available at: http://www.wepza.org/behindthewire/ bh181200.htm, Date of access: (15-06-2002). 